\title{
Sanitizer residues in the milk of cows which had passed through footbaths ${ }^{1}$
}

\author{
Daniel S. Goulart ${ }^{2 *}$, Camila F.P. Orlando-Goulart ${ }^{3}$, Jordanna A. e Silva ${ }^{4}$, Sabrina L.R. \\ Freitas $^{5}$, Leandro B.U. Caetano ${ }^{6}$, Maria C.S. Fioravanti ${ }^{7}$ and Luiz A.F. da Silva ${ }^{8}$
}

\begin{abstract}
Goulart D.S., Orlando-Goulart C.F.P., Silva J.A., Freitas S.L.R., Caetano L.B.U., Fioravanti M.C.S. \& Silva L.A.F. 2013. Sanitizer residues in the milk of cows which had passed through footbaths. Pesquisa Veterinária Brasileira 33(9):1076-1080. Escola de Veterinária e Zootecnia, Universidade Federal de Goiás, Cx. Postal 24267, Campus Universitário, Goiânia, GO 74690-970, Brazil. E-mail: dsgvet@hotmail.com

Copper sulfate and sodium hypochlorite are used in footbath solutions for the prevention and treatment of bovine digital diseases; however, data on the residues of such elements in milk are sparse in Brazil. This study evaluated the cost of applying the footbath treatment and the total amount of copper and chlorite residues in the milk of healthy cows after they had passed through these footbath solutions. Two groups of 7 cows each (GI and GII) were studied. In the case of GI, 1\% sodium hypochlorite was used and for GII 5\% copper sulfate was employed in the footbath. The milk samples were collected before the 7-day footbath treatment period (M0) and $24 \mathrm{~h}$ (M1), $48 \mathrm{~h}$ (M2), $72 \mathrm{~h}$ (M3) and 15 days (M15) after the last footbath. Statistical analysis to compare the different samples within each group was carried out by applying Friedman's test, followed by Dunn's test $(p<0.05)$. It was concluded that the amount of total chlorites and copper in the milk of healthy cattle after routine daily footbaths for a period of 7 days presented some variations. However, the concentrations observed were considered insufficient to represent a risk to human health. The cost of the footbath solutions was found to be reasonable.

INDEXING TERMS: Cattle, chlorites, digital illness, environmental contamination, sodium hypochlorite, copper sulfate.
\end{abstract}

RESUMO.- [Resíduos de sanitizantes em vacas de leite após passagem por pedilúvio.] 0 sulfato de cobre e $o$ hipoclorito de sódio são empregados na prevenção e tra-

\footnotetext{
${ }^{1}$ Received on June 3, 2013.

Accepted for publication on July 25, 2013.

${ }^{2}$ Doutorando em Ciência Animal, Escola de Veterinária e Zootecnia (EVZ), Universidade Federal de Goiás (UFG), Cx. Postal 24267, Campus Universitário, Goiânia, GO 74690-970, Brasil. Bolsista CAPES. *Corresponding author: dsgvet@hotmail.com

$\underline{3}$ Doutoranda em Ciência Animal, bolsista CNPq, EVZ-UFG, Caixa Postal 24267, Campus Universitário, Goiânia, GO 74690-970.

${ }^{4}$ Mestranda em Ciência Animal, Departamento de Clínica Médica, EVZ-UFG, Campus II Samambaia, Cx. Postal 131, Goiânia, GO 74001-970.

${ }^{5}$ Graduanda em Medicina Veterinária, EVZ-UFG, Cx. Postal 131, Goiânia, GO 74001-970. Bolsista de Iniciação Científica CNPq.

${ }^{6}$ Mestrando em Ciência Animal, EVZ-UFG, Av. General Couto Magalhães Q.21, Lt.16, Vila Mauá, Goiânia, GO 74323-240.

${ }^{7}$ Docente do Setor de Clínica e Cirurgia, EVZ-UFG, Cx. Postal 131, Goiânia, GO 74001-970.

${ }^{8}$ Docente do Setor de Clínica e Cirurgia, EVZ-UFG. Endereço particular: Rua 18-A, 591, Apto 502, Setor Aeroporto, Goiânia, G0 74070-060. Pesquisador Bolsista do CNPq.
}

tamento das enfermidades digitais dos bovinos, mas os valores residuais desses elementos foram pouco estudados. Neste estudo, avaliou-se a presença de resíduos de cobre e cloretos totais no leite de vacas saudáveis após passagens dos animais em pedilúvio contendo soluções formuladas com estas substâncias e estimou-se os custos das soluções. Utilizou-se 14 vacas saudáveis distribuídas em dois grupos (GI e GII) de sete animais cada. Em GI, empregou-se solução de hipoclorito de sódio a $1 \%$ e, em GII, sulfato de cobre a 5\%. As amostras de leite foram colhidas antes da passagem pelo pedilúvio (M0), após 24 (M1), 48 (M2) e 72 (M3) horas, além de 15 dias (M15) subsequentes à última passagem. Na análise estatística, a comparação entre momentos dentro de cada grupo foi realizada com teste de Friedman, seguido pelo teste de Dunn's $(p<0,05)$. Concluiu-se que os valores de cloretos totais e de cobre no leite de bovinos saudáveis, após passagens diárias dos animais em pedilúvio por um período de sete dias, apresentaram algumas variações consideradas insuficientes para provocarem danos à saúde humana 
e as soluções medicamentosas não apresentaram custos exorbitantes.

TERMOS DE INDEXAÇÃO: Hipoclorito de sódio, sulfato de cobre, cloretos, doenças digitais.

\section{INTRODUCTION}

Bovine digital diseases in dairy and beef cattle cause considerble losses, mainly associated with a reduction in the reproductive and zootechnical indexes, premature cull rates, treatment costs, and eventually death of the affected animals. The cost of treatment alone for such disorders can reach (US) \$72.58 per animal (Ferreira et al. 2004); but in relation to a reduction in milk production the financial loss could rise to (US) $\$ 95.80$ (Souza et al. 2006).

The negative influence of illnesses associated with cattle digits can be minimized by adopting preventive measures, mainly related to hygiene and humidity control in the stables, periodic herd health examinations, minimizing the distance walked by the animals, preventative hoof trimming, and the correct usage of footbaths.

The footbath is a low cost tool used to prevent digital diseases, which should be employed in association with other preventative measures since the use of the footbath alone is not as effective. In addition, the footbath can be applied at the same time for the prevention or treatment of digital diseases in both dairy and beef cattle (Silva et al. 2005, Janowicz et al. 2006).

Chemical products with disinfectant action are generally applied in footbaths. Such products aid the removal of organic matter or elements which irritate the hoof or accumulated between the claws. Applying such products contributes to the prevention and treatment of some lesions that may affect the digits of cattle (Nocek 1983).

The main chemical products used in footbath solutions are sodium hypochlorite (Silva et al. 2005), formaldehyde, zinc sulfate, and copper sulfate (Nocek 1993, Britt et al. 1996, Silva et al. 2005). Antibiotics such as oxytetracycline and lincomycin are also used (Seymour et al. 2002).

Even though some antibiotics are effective for treating some digital diseases of cattle in footbaths, occasionally traces of these medications can be found in the milk. In addition, over time, antibiotic use may induce the generation of resistant bacteria (Bryld et al. 2004).

Environmental consequences, especially residues entering water bodies, can also result from the use of antibiotics in footbath solution compositions (Nowrouzian \& Zareii 1998, Seymour et al. 2002, Bryld et al. 2004). Therefore, therapeutic protocols which exclude the use of antibiotics may be desirable (Bryld et al. 2004). It is also widely considered that, as in the case of antibiotics, some chemical products used in footbaths may also have adverse effects on humans, animals and the environment, resulting in a public health risk (Davis \& Wailes 2001, Klingberg 2005, Nuss 2006).

The objective of this study was to quantify residues of copper and total chlorites in the milk of healthy cattle after the animals had repeatedly passed through footbaths containing solutions formulated with copper sulfate or sodium hypochlorite.

\section{MATERIALS AND METHODS}

This study was carried out on 14 non-sick cross bred (Zebu x European) lactating cows with different body condition scores and body weights and an average daily milk yield of 10 liters. These cows belong to the herd of the Escola de Veterinária e Zootecnia da Universidade Federal de Goiás - EVZ-UFG. The research was conducted during March and April 2010 following the ethical precepts of the Colégio Brasileiro de Experimentação Animal (COBEA). The study was approved by the Ethics Committee on Research of the Federal University of Goiás under the protocol number 017/10.

Prior to the experiment, the cattle were submitted to an adaption period of 28 days. During this period they were managed applying the same standards to be applied during the experimental phase. This had a twofold purpose: (a) to facilitate the daily management and avoid resistance during the experimental phase and (b) to minimize the interference on each cow's behavior. For seven days, they passed daily through the footbath containing only water, and this water was changed every day.

A "foot-washer" was the dominating recipient structure of the footbath used both in the adaptation period and in the experimental phase. In the first tank, only water was used as a digital pre-cleaning agent and the second tank was placed right after this, where the animals came into contact with the medicating copper sulfate or sodium hypochlorite solutions. Each compartment was 3 meters (118 inches) long, 0.8 meter (31.5 inches) wide and 0.4 meter (15.75 inches) deep. The compartments were separated by a 1.5 meter (59 inches) ramp with a slope of $2 \%$ in the direction of the footbath tank. A gate installed between tanks permitted controlled access to the cattle such that only one animal could pass at a time through the tank containing the sanitizer solution. The medicating solution layer was 10 centimeters (3.9 inches) thick, and the tank entry and exiting access ramps were 50 centimeters (19.7 inches) long, placed on concrete and grooved sideways.

Both in the pre-experimental and experimental phases, the animals grazed on Brachiaria decumbens pastures as their main nutritional source. They also had access to water from drink dispensers and a commercial mineral mixture (Guabiphos 80 leite, GrupoGuabi, Anápolis, Goiás), both ad libitum. During the adaptation phase, all animals were submitted to a general clinical examination.

A specific examination of the locomotive system had been performed previously (Radostits, Mayhew \& Houston 2002), with an emphasis on digital health. The locomotive system of the animals was evaluated through observation of their posture and locomotion, combined with a visual evaluation of each digit (Shearer et al. 2012).

In parallel, at the Nutrition and Research Center EVZ-UFG (CPA), a somatic cell count (SCC) was performed to determine the condition of the cows' mammary glands, using a Fossomatic 5000 Basic $^{\circledR}$ apparatus (Foss Eletric, Hillerod, Denmark). The animals with an SCC of 200,000 or less were eligible to participate in the experiment.

All of the cows participating in the study were orally dosed with an anthelmintic agent based on $10 \%$ albendazole (Aldazole 10 CO, Vallé S. A., São Paulo, SP, Brazil). Animals also were sprayed with Cypermethrin (Cypermil Plus Pulverização ${ }^{\circledR}$, OuroFinoAgronegócios, Cravinhos, SP, Brazil).

The research started at the end of the preparatory phase. To evaluate the residues, the cattle were separated into two groups of seven animals each (GI and GII). Sodium hypochlorite and copper sulfate were used as the main active elements in the two solutions (one for each group) prepared for the footbaths. Both products were obtained commercially. The animals passed through the foo- 
tbaths containing the respective sanitizer solutions, according to the groups established, for seven consecutive days. The sanitizer solutions were changed every three days.

The first milk sample was collected before the animals passed through the footbaths. Four other samples were then collected at different time periods after the end of the seven days of daily foot bathing. The samples collected before the animals started the footbath treatment were considered moment zero (M0), and those collected at 24 hours, 48 hours and 72 hours after passing through the footbath on the seventh day were denoted as (M1), (M2) and (M3). Later, a fifth collection was carried out 15 days after the cattle had passed through the footbath on the seventh day and this was denoted as (M15).

For all of these collections, a sample of each cow's milk was collected after the milking had been completed and the product obtained homogenized in an adequate container. A sample of 300 $\mathrm{ml}$ was collected from each animal regardless of the individual milk output.

The milk samples were stored in thermal boxes immediately after collection and then sent to the laboratory. At the laboratory the samples were stored under refrigeration at $5^{\circ} \mathrm{C}\left(41^{\circ} \mathrm{F}\right)$ until processing.

The level of copper residue was evaluated using an atom absorbence spectrometer, following the methodology of Gonçalves (2007).

The total chlorites content was determined using a spectrophotometer (BIO-2000, BioPlus Produtos para Laboratórios Ltda, São Paulo, SP, Brazil), and a commercial kit (Cloretos, Labtest Diagnóstica Ltda, Lagoa Santa, MG, Brazil).

The costs for the preparation of both the sodium hypochlorite and copper-sulfate solutions were estimated. In the calculations, only the commercial costs of obtaining the products sodium hypochlorite in a concentration of $10 \%$ and pentohydrated copper sulfate by the liter or by the kilogram, respectively, were considered. The cost of preparing 100 liters of each solution was calculated in both Brazilian reais (R\$) and (US\$) US dollars.

The data obtained from the laboratory evaluation were submitted to the program Graph Pad InStat $\AA$ (GraphPadInStat for Windows, version 3.00, GraphPad Software, Inc, USA (USA, in Brazilian format)). The comparison of the copper sulfate or sodium hypochlorite contents of the samples collected from each group was carried out by applying the Friedman test, followed by the Dunn test. The findings were considered significant when $\mathrm{p}<0.05$ (Sampaio 1998).

\section{RESULTS}

The data in Table 1 represent the levels of chlorites found in the cow's milk samples before and after the animals passed through the footbaths containing 1\% sodium hypo-

Table 1. Concentration of chlorites ( $\mathrm{mEq} / \mathrm{l})$ in clinically healthy cows' milk, before and after repeated foot bathing in an experiment performed at College of Veterinary Science and Animal Husbandry of Federal University of Goiás between March and April 2010

\begin{tabular}{lccccc}
\hline & M0 & M1 & M2 & M3 & M15 \\
\hline Average & $28.07 \mathrm{a}$ & $60.14 \mathrm{ab}$ & $70.86 \mathrm{~b}$ & $42.71 \mathrm{a}$ & $54.14 \mathrm{ab}$ \\
DesPad & 5.85 & 17.22 & 21.91 & 20.85 & 19.69 \\
CoefVar & 20.85 & 28.63 & 30.92 & 48.80 & 36.37
\end{tabular}

Different letters in the same line show significant difference $(p<0.05)$. DesPad $=$ standard deviation, CoefVar $=$ coefficient of variation, $\mathrm{M} 0=$ before treatment, and M1 $=24 \mathrm{~h}, \mathrm{M} 2=48 \mathrm{~h}, \mathrm{M} 3=72 \mathrm{~h}$ and M15 $=15$ days after treatment. chlorite (average value, standard deviation and coefficient of variation).

The chlorite levels of the milk collected from the animals of group G1, before and after passing through the footbaths, increased gradually from M0, staring at $28.07 \mathrm{mEq} / \mathrm{l}$ and reaching $70.86 \mathrm{mEq} / \mathrm{l}$ at $\mathrm{M} 2$.

The data obtained for the chlorite content before and after the animals passed through the footbaths were significantly different when comparing M2 with M0, and M2 with M3. However, there was no significant difference between the results for M0 and the samples M1, M3, and M15 $(\mathrm{p}<0.05)$. There was also a reduction in chlorite levels from M2 to M15, although this was not statistically significant.

For the copper levels, on comparing M1 with M2, M1 with M3 and M1 with M15 the values were significantly different $(\mathrm{p}<0.05)$. However, there was no significant difference when M0 was compared with the samples M1, M2, M3 and M15.

There was a decrease in the copper levels in the milk after M2, although this was not statistically significant. Table 2 shows the results for the average, standard deviation and coefficient of variation relating to the level of copper found in the milk.

Table 2. Copper concentrations $(\mathrm{mg} / \mathrm{kg})$ in milk of clinically healthy cows before and after repeated foot bathing in an experiment performed at College of Veterinary Science and Animal Husbandry of Federal University of Goiás between March and April of 2010

\begin{tabular}{lccccc}
\hline & M0 & M1 & M2 & M3 & M15 \\
\hline Average & $0.493 \mathrm{ab}$ & $0.322 \mathrm{a}$ & $0.681 \mathrm{~b}$ & $0.555 \mathrm{~b}$ & $0.608 \mathrm{~b}$ \\
DesPad & 0.093 & 0.110 & 0.225 & 0.128 & 0.154 \\
CoefVar & 18.956 & 34.173 & 33.125 & 23.163 & 25.316
\end{tabular}


DesPad $=$ standard deviation, CoefVar $=$ coefficient of variation, $\mathrm{M} 0=$ before treatment, and M1 $=24 \mathrm{~h}, \mathrm{M} 2=48 \mathrm{~h}, \mathrm{M} 3=72 \mathrm{~h}$ and M15 $=15$ days after treatment.

Considering the concentrations used in both solutions analyzed it was estimated that the cost to prepare $100 \mathrm{li}-$ ters (26.42 US gallons) of the solution with $1 \%$ sodium hypochlorite was $\mathrm{R} \$ 11.16$ (approx. US $\$ 6.56$ ) and the corresponding cost for the $5 \%$ copper sulfate solution was $\mathrm{R} \$$ 42.50 (approx. US \$25.00).

\section{DISCUSSION}

The adaptation period was fundamental in order to condition the cattle and accustom them to the daily activities of the experiment, especially leading them through the footbaths. On analyzing the behavior of the cattle throughout the study it was observed that after the adaptation period the animals were less reluctant to be driven through the footbaths.

Also, it was apparent that there was a decrease in the quantity of expelled excrement. This is considered to indicate that the adaptation procedure was successful, since it made the animal less hostile to manage. In addition, the apparent reduction in the volume of excrement could have minimized the contamination of the solutions. 
According to Degasperi et al. (2003), submitting cattle to excitement, the presence of strangers, abuse and bad behavior, or any other traumatizing effects, generally results in immediate urine or feces elimination.

The significant difference observed in the chlorite content when comparing samples M0 and M2, for group G1, could be attributed to potential chlorite absorption by the hoof as well as by the inter-digital tissue, although this would involve only small quantities.

In this context, the increase in the chlorite levels in the milk samples from M1 to M2 with a subsequent decrease observed for M3 (although this was not statistically significant), could have been influenced by external factors such as ingesting pasture, mineral salts or chlorinated water.

It should also be noted that since the animals were fed by grazing, it is possible they could have ingested different quantities of feed. If so, this may have altered the chlorite levels of the milk. According to Silva (1997), milk contents can be affected by the species, race, physiology (individuality, difference between udders, and age), feed, season of the year, illness, lactation period and milking characteristics (frequency and process applied).

Although there was evidence of increased levels of chlorite after the cattle passed through the footbaths, the enhanced concentrations are not considered to be harmful to the consumer. The chlorite concentrations detected in the samples analyzed are similar to the values reported by Zarfalon et al. (2005). According to these researchers, the levels of chlorite detected in healthy cow's milk were in the range of $1240-1660 \mathrm{mg} / \mathrm{kg}$, and in cows with subclinical mastitis the average values were in the range of 1570$2550 \mathrm{mg} / \mathrm{kg}$. These levels are similar to those reported herein, since on converting the data obtained in this study from $\mathrm{mEq} / \mathrm{l}$ to $\mathrm{mg} / \mathrm{kg}$, the chlorites varied from 996.54 to 2515.43. Therefore, sodium hypochlorite could represent an appropriate alternative for preparing sanitizer solutions for use in footbaths.

Regarding the copper levels, the significant variations detected in the M1and M2, M3 and M15 samples, reinforce the hypothesis that both chlorite as well as copper levels can be influenced by external factors. In this context, the quantities of different components in milk can be altered by feeding regimes, according to Silva (1997).

A considerable variation in the copper levels was observed in this study, but the concentrations are still in agreement with the values observed by Gonçalves et al. (2008) who reported copper levels in milk of between 0.390 and $0.590 \mathrm{mg} / \mathrm{kg}$ in various areas in the state of Goiás, and affirmed that there is a large variation in copper levels in dairy products. Moreover, based on the results of this study and on the findings by the cited authors, it can be verified that there are instability indexes in copper levels in cow's milk.

Despite the fact that the copper levels detected in the milk of the cows evaluated are higher than those cited by some authors, such as Gonçalves et al. (2008), the consumption of such milk is not considered to be harmful to humans.

According to Danks (1998) and to the "Guide for drinking-water quality" published by the World Health Organization
(WHO) safe copper consumption by humans is established at between 1.0 and $2.0 \mathrm{mg}$; values higher than those obtained for the samples analyzed in this study. Also, considering the recommended intake of copper by humans, a person could consumption the milk analyzed in this study, since the copper concentrations did not surpass $0.930 \mathrm{mg} / \mathrm{kg}$.

However, the possibility of copper accumulation in an organism over time should not be neglected. Moreover, other foods with high copper levels may also be consumed, causing the intake of this metal to be unacceptable high.

Similarly, it should be noted that the possibility of copper absorption is higher in the case of animals with digital lesions since, when they pass through the footbaths containing solutions prepared with this element, open sores facilitate assimilation by the organisms.

On analyzing the estimated costs for the two solutions, it can noted that the recommendation of Silva et al. (2005), that is, to alternate the therapeutic medication protocols, represents a viable option for treating illness in cattle digits. According to the cited authors, a solution based on copper is acid and with a solution based on sodium hypochlorite is alkali, substances that could kill bacteria and fungi.

According to Ruiz (1992) bacteria grow better at near neutral $\mathrm{pH}$ while fungi prefer an acid environment with $\mathrm{pH}$ levels between 1 and 5. Thus, the inclusion of both sanitizer elements in the cow footbaths tested here is recommended.

Another favorable aspect related to the use of footbaths is the cost of the solutions. For example, 200 liters (52.83 US gallons) of a $5 \%$ copper sulfate solution would cost $\mathrm{R} \$ 85.00$ (approx. US\$47.00). According to Greenough (2007), a footbath with this quantity solution could be used for up to 250 animals without having to be replaced. Thus, if the footbaths are to be used twice a week over a one year period, each animal will go through the footbaths 104 times.

Therefore, considering a total of 250 passages, the cost for each animal's preventive treatment would be $\mathrm{R} \$ 0.34$ (approx. US\$0.18) and the annual cost for each animal would be R $\$ 35.36$ (approx. US\$ 20.08), a much lower cost than the (US) $\$ 72.58$ required to treat digital illness cited by Ferreira et al. (2004) or the cost of (US) $\$ 95.80$ reported by Souza et al. (2006).

This cost becomes even more accessible on considering the alternation of a $5 \%$ copper solution with $1 \%$ hypochlorite, where for each hygiene treatment process the solution in the footbath would be changed.

Therefore, applying the same estimate, the annual cost per animal reaches R $\$ 22.25$ (US $\$ 13.09$ ). This value represents $18.03 \%$ and $13.66 \%$ of the costs in treating digital illness cited by Ferreira et al. (2004), and Souza et al. (2006), respectively.

Consequently, the use of footbaths could not only decrease the occurrence of digital illness but also increase the working life of the animals. This would avoid the premature discarding of cows, which could generate substantial savings for the producer.

Research on farms using these formulas should be carried out in future studies in order to increase our knowledge on these treatments. It would then be possible to evaluate other concentrations for periods greater than seven days 
using cattle which have had digital illness treated surgically.

Lastly, based on the favorable results reported herein, scientific research needs to be carried out keeping the animals in a controlled environment, in an attempt to evaluate the stability of the active principles investigated in this study.

Furthermore, in this regard, controlled feeding could minimize the effects of forage obtained by grazing on the concentrations of the components under study. However, the possibility of copper and chlorite absorption due to contact with open sores, as a result of surgical treatment of digital lesions, should not be neglected. This could facilitate the absorption of these elements by the organism and thus enhance their levels in the milk. In addition, there is clearly a need to initiate scientific studies to verify the levels of these residues in the soil, water and environment.

\section{CONCLUSIONS}

The total concentrations of chlorites and copper identified in the milk of healthy cattle, after they had passed through footbaths with these elements in their formulated solutions, showed variations within ranges considered to be insufficient to represent a threat to human health.

The costs associated with these treatment solutions are very attractive.

\section{REFERENCES}

Britt J.S., Gaska J., Garret E.F., Konkle D. \& Mealy M. 1996. Comparison of topical application of three products for treatment of papillomatous digital dermatitis in dairy cattle. J. Am. Vet. Med. Assoc. 209(6):1134-1136.

Brydl E., Jurkovich V., Könyves L., Tirían A.E., Alexov M. \& Vona F. 2004. Treatment of Digital Dermatitis Without using of antibiotics: A clinical trial. $13^{\text {th }}$ International Symposium and $5^{\text {th }}$ Conference on Lameness in Ruminants. Maribor, Slovenija, p.150-151.

Danks D.M. 1988. Copper deficiency in humans. Annual Reviews 8:235257.

Davis J. \& Wailes B. 2001. Cooper in dairy footbaths: a problem for crops and cows? Integrated Livestock Management. Available at: <http:// www.cvmbs.colostate.edu/ilm/proinfo/cdn/2001articles/footbathCuNov01.pdf> Access on Dez. 20, 2010.

Degasperi S.A.R., Coimbra C.H., Pimpão C.T., Souza F.P., Chi K.D., Junior P.G., Ernlund R., Macedo F., Piekarski P.R.B., Almeida R., Barbosa A., Karan W.M., Pereira A.T., Huber A.R., José A., Ferreira M., Morestto C.J., Scholz D., Mercer E.A., Manzini E., Jazar F.W., Zoccoli G., Toledo I., Paula M., Janzen P., Napoli R., Kleig S. \& Costa T.S. 2003. Estudo do comportamento do gado holandês em sistema de semi-confinamento. Revta Acadêmica, Ciências Agrárias e Ambientais 1(4):41-47.

Ferreira P.M., Leite R.C., Carvalho A.U., Facury Filho E.J., Souza R.C. \& Ferreira M.G. 2004. Custo e resultados do tratamento de seqüelas de laminite bovina: relato de 112 casos em vacas em lactação no sistema free-stall. Arq. Bras. Med. Vet. Zootec. 56(5):589-594.
Gonçalves J.R. 2007. Metais pesados em vísceras bovinas do Estado de Goiás. Tese de Doutorado em Ciência Animal, Escola de Veterinária, Universidade Federal de Goiás, Goiânia, GO.132p.

Gonçalves J.R., Mesquita A.J. \& Gonçalves R.M. 2008. Determinação de metais pesados em leite integral bovino pasteurizado no estado de Goiás. Ciênc. Anim. Bras. 9(2):365-374.

Greenough P.R. 2007. Claw trimming, foot baths, restraint, bandaging, lifts, and shoes, p.170-198. In: Ibid. (Eds), Bovine Laminitis and Lameness. W.B. Saunders, London.

Janowicz P., Bathina H., Durkin J. \& Hemling T. 2004. Foot bathing in the hoof health management. $13^{\text {th }}$ International Symposium and $5^{\text {th }}$ Conference on Lameness in Ruminants, Maribor, Slovenija, p.28-29.

Klingberg K. 2005. Copper sulfate foot bath treatment for animal health: impact on manure nutrient content, Crops, Soil and Environment. Available at: <http://www.uwdiscoveryfarms.org/newpubs/publications/ Copper\%20Sulfate_Footbath.pdf $>$ Access on Sept. 7, 2009.

Nocek J.E. 1993. Hoof Care for Dairy Cattle. $2^{\text {nd }}$ ed. W.D. Hoard and Som Company, Fort Atkinson. 39p.

Nowrouzian I. \& Zareii S. 1998. Comparison of two application forms of Linocomycim HCL for group treatment of digital dermatitis in dairy cows. $10^{\text {th }}$ International Symposium on Lameness in Ruminants, Lucerne, Switzerland, p.287-289.

Nuss K. 2006. Footbaths: The solution to digital dermatitis? Vet. Journal 171(1):11-13.

Radostits O.M., Mayhew I.G.J. \& Houston D.M. 2002. Exame Clínico e Diagnóstico em Veterinária. Guanabara Koogan, Rio de Janeiro, p.519-569.

Ruiz R.L. 1992. Introdução ao estudo dos microrganismos, p.1-15. In: Ibid. (Ed.), Microbiologia Zootécnica. Roca, São Paulo.

Sampaio I.B.M. 1998. Estatística Aplicada à Experimentação Animal. Fundação de Ensino e Pesquisa em Medicina Veterinária e Zootecnia, Belo Horizonte. 221p.

Seymour J., Durkin J., Bathina H. \& Hemling T. 2002. Footbathing in the Management of Digital Dermatitis. $12^{\text {th }}$ International Symposium on Lameness in Ruminants, Kansas, USA, p.374-376.

Shearer J.K., Amstel S.R.V., Brodersen B.W. 2012. Clinical diagnosis of foot and leg lameness in cattle. Vet. Clin. Food. Anim. 28:535-556.

Silva L.A.F., Silva C.A., Borges J.R.J., Fioravanti M.C.S., Borges G.T. \& Atayde I.B. 2005. A clinical trial to assess the use of sodium hypochlorite and oxytetracycline on the healing of digital dermatitis lesions in cattle. Can. Vet. J. 46(4):345-348.

Silva P.H.F.S. 1997. Leite: aspectos de composição e propriedades. Química Nova na Escola 6:3-5.

Souza R.C., Ferreira P.M., Molina L.R., Carvalho A.U. \& Facury Filho E.J. 2006. Perdas econômicas ocasionadas pelas enfermidades podais em vacas leiteiras confinadas em sistema free stall. Arq. Bras. Med. Vet. Zootec. 58(6): 982-987.

Zafalon L.F., Nader Filho A., Amaral L.A., Oliveira J.V. \& Resende F.D. 2005. Alterações da composição e da produção de leite oriundo de quartos mamários de vacas com e sem mastite subclínica de acordo com o estágio e o número de lactações. Arqs Inst. Biológico, São Paulo, 72(4):419-426.

Zemljic B. 2004. Influence of foot bathing on prevalence of digital dermatitis after introduction of diseased animal into healthy dairy herd. $13^{\text {th }}$ International Symposium, and Conference on Lameness in Ruminants, Maribor, Slovenija, p.145-146. 